\title{
Effects of mixing red clover with alfalfa at different ratios on dynamics of proteolysis and protease activities during ensiling
}

\author{
Xujiao Li, ${ }^{*}$ Jipeng Tian,† Qing Zhang,‡ Yun Jiang,§ Zhe Wu, ${ }^{*}$ and Zhu Yu*1 \\ *Institute of Grassland Science, China Agricultural University, Beijing, China, 100193 \\ †Institute of Livestock Science, Jiangsu Academy of Agricultural Science, Nanjing, China 210014 \\ $\ddagger$ College of Forestry and Landscape Architecture, South China Agricultural University, Guangzhou, China 510642 \\ §Department of Animal Sciences, University of Florida, Gainesville 32611
}

\begin{abstract}
This study was conducted to study the effects of ensiled alfalfa (Medicago sativa) and red clover (Trifolium pratense) at different ratios on dynamics of fermentation parameters, $\mathrm{N}$ distribution, protein fractions, and protease activities during ensiling. Alfalfa and red clover were harvested and wilted to 35 and $25 \%$ dry matter, respectively, chopped to $1 \mathrm{~cm}$, mixed, weighed into 1.0-L buckets at a density of $700 \mathrm{~g} / \mathrm{L}$, and ensiled for $1,3,7,15$, and $30 \mathrm{~d}$ at $30^{\circ} \mathrm{C}$. The treatments were mixing ratio of alfalfa to red clover at 100:0, 70:30, 50:50, 30:70, and 0:100 (R0, R30, R50, R70, and R100, respectively; fresh weight). For each ensiling duration, 3 replicates of each treatment were prepared. With increasing proportion of red clover in silage, total $\mathrm{N}$ content and proportions of nonprotein $\mathrm{N}$, peptide $\mathrm{N}$, free amino acid $\mathrm{N}$, and $\mathrm{NH}_{3}-\mathrm{N}$ decreased linearly, and PC (indigestible true protein, acid detergent insoluble $\mathrm{N})$ proportion increased linearly after ensiling. Moreover, the final $\mathrm{pH}$ was lower in R50 and R100 than R0 (4.29, 4.20 vs. 4.48, respectively) on d 30. Also, lactic acid concentration on d 30 was higher in R50, R70, and R100 silage compared with R0 (7.77, 7.66, and 8.76 vs. $6.34, \%$ of dry matter, respectively). The proportion of $\mathrm{NH}_{3}-\mathrm{N}$ in $\mathrm{R} 50$ was lower than in $\mathrm{R} 0$ but closer to R100 after ensiling. During ensiling, proteases including carboxypeptidase, aminopeptidase, and acid proteinase activities decreased as red clover proportion increased. However, no differences were detected in aminopeptidase and acid proteinase activities among R50, R70, and R100 during ensiling. Overall, 50:50 was the optimal mixing ratio of alfalfa with red clover, showing good fermentation quality with lower $\mathrm{pH}$ and higher lactic acid concentration, reduced protease activities
\end{abstract}

Received March 18, 2018.

Accepted May 29, 2018.

${ }^{1}$ Corresponding author: yuzhu33150@sina.com and proteolysis compared with pure alfalfa silage, and also more total $\mathrm{N}$ content than pure red clover silage.

Key words: proteolysis, silage, alfalfa, red clover

\section{INTRODUCTION}

Extensive proteolysis occurs during the ensiling of alfalfa (Medicago sativa). Part of the true protein is degraded to NPN including mainly peptides, free amino acids (FAA), and $\mathrm{NH}_{3}-\mathrm{N}$ (McDonald et al., 1991). In ensiled alfalfa, NPN can account for 44 to $87 \%$ of total protein (Papadopoulos and Mckersie, 1983; Muck, 1987). In addition, the availability of true protein also decreases in alfalfa silage because of the increasing amount of bound true protein (Guo et al., 2008). When alfalfa silage or alfalfa hay were fed to lactating dairy cows, although higher DM digestibility was observed in cows fed the silage, the higher concentration of ruminal $\mathrm{NH}_{3}$ and milk urea- $\mathrm{N}$ indicated poor $\mathrm{N}$ utilization of alfalfa silage (Broderick, 1995). The economic loss and potential environmental pollution call for a better approach to minimize proteolysis in alfalfa during ensiling.

Compared with alfalfa, red clover (Trifolium pratense) shows a lower proteolysis rate as reflected in lower soluble NPN (6.8 to 40.8 vs. 18.9 to $66.8, \%$ of total N, TN) during ensiling (Papadopoulos and Mckersie, 1983). Various studies have attributed inhibited proteolysis to polyphenol oxidase (PPO; EC 1.10.3.1; Mayer, 1986), a copper-containing enzyme naturally present in red clover (Jones et al., 1995b; Sullivan and Hatfield, 2006). After cutting or crushing, PPO enzymes in red clover are released from the cell and catalyze the oxidation of endogenous o-diphenols to quinones in the presence of oxygen (Macheix et al., 1991). Quinones then are polymerized to cross-linked protein complexes, resulting in inhibition of protein degradation (Bittner, 2006).

Protein protection was not found in ensiled transgenic alfalfa expressing PPO due to the lack of endogenous phenolic substrate (Getachew et al., 2009). Sullivan and Zeller (2013) found reduced proteolysis in alfalfa genetically altered to express PPO when they added 
$o$-diphenols and ensiled that alfalfa. Both PPO and odiphenol substrate may be added to alfalfa by mixing alfalfa with red clover. A few studies attempted to ensile alfalfa with red clover to reduce proteolysis. Jones et al. (1995b) reported that mixing red clover extract and alfalfa extract at 1:1 ratio reduced alfalfa proteolysis by $70 \%$ compared with untreated alfalfa extract in laboratory scale. Marley et al. (2003) ensiled alfalfa/ red clover bi-crops in 5 sowing ratios and reported that after ensiling, soluble $\mathrm{N}$ and FAA concentrations decreased with increasing red clover percentage and 1:1 was the optimal sowing ratio. However, in their study, sowing ratios do not reflect the final ratios of alfalfa and red clover at ensiling due to different growth of plants. Other indicators of proteolysis, protein fractions, and protease activities were not measured in their study. Furthermore, Broderick et al. (2001) and Broderick (2018) reported that lactating dairy cows can use $\mathrm{N}$ from red clover more efficiently than that from alfalfa as reflected in lower urea in milk and blood, and less $\mathrm{N}$ excretion without reducing milk yield and BW. These studies indicate that ensiling red clover with alfalfa has the potential to inhibit proteolysis and improved protein utilization by animals.

The objectives of this study were to evaluate the effects of ensiling alfalfa mixed with red clover at different ratios on dynamics of protein degradation and protease activities during the ensiling and determine the optimal mixing ratio for good fermentation quality and protein preservation. We hypothesize that ensiling red clover with alfalfa can improve fermentation quality, inhibit protease activities, and reduce proteolysis of the silage without negative effects on fermentation quality.

\section{MATERIALS AND METHODS}

\section{Forage and Treatments}

Alfalfa (WL525, Forage Genetics International, Nampa, ID) and red clover (Badong, China) were planted at the experimental farm of the Institute of Animal Sciences of Hubei Academy of Agricultural Sciences (Wuhan, China) and applied with no herbicides and fertilizers. Legumes were harvested at full bloom in third cutting, using a sickle by hand and leaving a $5 \mathrm{~cm}$ stubble. After chopping to approximately $1 \mathrm{~cm}$ with a forage cutter (Lingong Machinery, Shandong, China), alfalfa was wilted in the field for $4 \mathrm{~h}$ to reach a DM concentration of $35 \%$; meanwhile, red clover was wilted to 25\% DM. Microwave (M1-L213B, Midea Group Co., Ltd., Foshan, China) was used for rapid determination of DM (Farmer and Brusewitz, 1980). Alfalfa and red clover were mixed at ratios of 100:0,
70:30, 50:50, 30:70, and 0:100 (R0, R30, R50, R70, and R100, respectively, fresh weight, $\mathbf{F W})$. All treatments received Lactobacillus plantarum $\left(1 \times 10^{6} \mathrm{cfu} / \mathrm{g}\right.$ of $\left.\mathrm{FW}\right)$ plus sucrose $(4 \mathrm{~g} / \mathrm{kg}$ of $\mathrm{FW})$ to facilitate fermentation. The lactic acid bacteria strain (GenBank accession number: KX870021) was isolated from cucumber pickle by the silage laboratory of China Agricultural University and identified as L. plantarum by $16 \mathrm{~S}$ rRNA gene sequencing (Cai, 1999). Additive was dissolved in distilled water and sprayed at $10 \mathrm{~mL} / \mathrm{kg}$ of $\mathrm{FW}$ on ensiling materials. After mixing, approximately $700 \mathrm{~g}$ of material was packed into 1.0-L plastic buckets (Hewanglan Paper and Plastic Products Factory, Beijing, China) to achieve a packing density of $700 \mathrm{~g} / \mathrm{L}$. A total of 15 silos were prepared for each treatment and stored in an incubator (SPX-250, Beijing Luxi Tech. Co. Ltd., Beijing, China) with temperature set at $30^{\circ} \mathrm{C}$. Three silos from each treatment were opened on $1,3,7,15$, and $30 \mathrm{~d}$, respectively.

\section{Chemical Composition Analysis}

Subsample of fresh forage before ensiling and treated silage after silo opening was dried in an oven (GZX9140MBE, Shanghai Boxun Co. Ltd., Shanghai, China) at $65^{\circ} \mathrm{C}$ for $48 \mathrm{~h}$ for DM measurement. The dry samples were ground to pass through a 1-mm screen using a mill (FZ102, Test Instrument, Tianjin, China) and stored for further chemical analysis. Concentrations of NDF and ADF were determined as described by Van Soest et al. (1991) in an Ankom Fiber Analyzer (A2000I, Ankom Technology, Macedon, NY). Thermostable $\alpha$-amylase and sodium sulfite were used in the NDF analysis, and the results were expressed on a DM basis without residual ash.

Twenty grams of each silage sample was mixed with $180 \mathrm{~mL}$ of distilled water and homogenized in a blender for $60 \mathrm{~s}$, and filtered through 4 layers of cheesecloth and filter paper successively (Tian et al., 2017). The $\mathrm{pH}$ value was measured immediately using a $\mathrm{pH}$ meter (PHS-3C, INESA Scientific Instrument, Shanghai, China). The concentrations of organic acids including lactic, acetic, propionic, and butyric acid were measured by HPLC (Shimadzu, Tokyo, Japan; Xu et al., 2007).

\section{Protein Degradation Indicator Analysis}

Contents of FAA-N and $\mathrm{NH}_{3}-\mathrm{N}$ were determined according to Broderick and Kang (1980). Total N was measured using the Kjeldahl nitrogen analyzer (Kjeltec 2300 Auto-Analyzer, FOSS Analytical AB, Hoganas, Sweden) according to AOAC (1990). Proportion of total buffer soluble N, NDIN, and ADIN were deter- 
mined as described by Licitra et al. (1996). Protein fractions $\left(\mathrm{PA}_{1}, \mathrm{PA}_{2}, \mathrm{~PB}_{1}, \mathrm{~PB}_{2}\right.$, and $\left.\mathrm{PC}\right)$ were calculated according to the Cornell Net Carbohydrate and Protein System (CNCPS; Higgs et al., 2015). Peptide-N proportion was calculated by subtracting $\mathrm{NH}_{3}-\mathrm{N}$ and FAA-N proportions from NPN (Licitra et al., 1996).

\section{Protease Activity Analysis}

Protease extracts were prepared using the method of Guo et al. (2007). After silos were opened, $20 \mathrm{~g}$ subsample of each silo was homogenized with $100 \mathrm{~mL}$ of 0.1 $M$ sodium phosphate buffer (pre-cooling, pH 6.0 with $5 \mathrm{~m} M$ hyposulfite) for $60 \mathrm{~s}$. The homogenates were filtered through 4 layers of cheesecloth and centrifuged at $8,000 \times g$ for $10 \mathrm{~min}$ at $4^{\circ} \mathrm{C}$. The supernatant samples were stored at $-80^{\circ} \mathrm{C}$ for analysis of protease activities. Acid proteinase activity was measured by the methods of Peterson and Huffaker (1975) modified by Guo et al. (2007). Aminopeptidase and carboxypeptidase activities were determined according to the method of Feller et al. (1977).

\section{Statistical Analysis}

The experiment was a completely randomized design with a $5 \times 6$ ( 5 treatments and 6 opening days $)$ factorial arrangement. The MIXED procedure of SAS (version 9.1, SAS Institute Inc., Cary, NC) was used to test effects of mixing ratio, ensiling time, and their interaction over the ensiling period. The model used was

$$
\mathrm{Y}=\mu+\mathrm{T}_{\mathrm{i}}+\mathrm{D}_{\mathrm{j}}+\mathrm{T}_{\mathrm{i}} \times \mathrm{D}_{\mathrm{j}}+\varepsilon_{\mathrm{ijk}}
$$

where $\mathrm{Y}$ was the response variable, $\mu$ was the overall mean, $T_{i}$ was the treatment effect, $D_{j}$ was the effect of ensiling duration, and $\varepsilon_{\mathrm{ijk}}$ was the residual error. Post hoc mean comparisons were compared with Duncan's multiple comparisons. Significance was declared at $P$ $\leq 0.05$.

The GLM procedure of SAS (version 9.1, SAS Institute Inc.) was used to test the effects of mixing ratio for each ensiling duration. The model used was

$$
\mathrm{Y}=\mu+\mathrm{T}_{\mathrm{i}}+\varepsilon_{\mathrm{ij}}
$$

where $\mathrm{Y}$ was the response variable, $\mu$ was the overall mean, $T_{i}$ was the effect of treatment (mixing ratio), and $\varepsilon_{i j}$ was the residual error. Orthogonal polynomial contrasts of SAS were used to determine linear and quadratic responses to the level of red clover incorporation on fermentation parameters, $\mathrm{N}$ distribution, and protein fractions in silage on $\mathrm{d} 30$. The coefficients of polynomial contrasts were generated in PROC IML for the unequally spaced inclusion levels of red clover. Significance was declared at $P \leq 0.05$.

\section{RESULTS}

\section{Chemical Compositions of Alfalfa, Red Clover, and Their Mixture Before Ensiling}

The chemical compositions of alfalfa, red clover, and their mixtures before ensiling are listed in Table 1. With increasing proportion of red clover, the contents of DM, TN, and proportions of FAA-N and $\mathrm{NH}_{3}-\mathrm{N}$ decreased, whereas NDIN and ADIN proportions increased linearly. No differences in NPN and peptide-N

\begin{tabular}{|c|c|c|c|c|c|c|c|c|c|}
\hline Item $^{1}$ & \multicolumn{5}{|c|}{ Treatment $^{2}$} & SEM & \multicolumn{3}{|c|}{$P$-value ${ }^{3}$} \\
\hline$\overline{\mathrm{DM}, \%}$ & $34.5^{\mathrm{a}}$ & $31.5^{\mathrm{b}}$ & $29.7^{\mathrm{c}}$ & $27.8^{\mathrm{d}}$ & $24.9^{\mathrm{e}}$ & 0.88 & $<0.001$ & $<0.001$ & 0.90 \\
\hline $\mathrm{ADF}, \%$ of DM & 35.7 & 35.4 & 34.6 & 35.0 & 33.9 & 0.20 & 0.07 & 0.01 & 0.75 \\
\hline TN, $\%$ of DM & $2.69^{\mathrm{a}}$ & $2.63^{\mathrm{ab}}$ & $2.60^{\mathrm{ab}}$ & $2.57^{\mathrm{bc}}$ & $2.52^{\mathrm{c}}$ & 0.02 & 0.009 & $<0.001$ & 0.99 \\
\hline NPN, $\%$ of TN & 28.3 & 27.2 & 26.6 & 25.5 & 24.6 & 0.54 & 0.23 & 0.03 & 0.999 \\
\hline $\mathrm{NH}_{3}-\mathrm{N}, \%$ of $\mathrm{TN}$ & $1.26^{\mathrm{a}}$ & $1.07^{\mathrm{b}}$ & $0.93^{\mathrm{c}}$ & $0.74^{\mathrm{d}}$ & $0.51^{\mathrm{e}}$ & 0.07 & $<0.001$ & $<0.001$ & 0.33 \\
\hline NDIN, $\%$ of TN & $22.4^{\mathrm{e}}$ & $25.0^{\mathrm{d}}$ & $27.8^{\mathrm{c}}$ & $30.7^{\mathrm{b}}$ & $34.7^{\mathrm{a}}$ & 1.19 & $<0.001$ & $<0.001$ & 0.38 \\
\hline ADIN, $\%$ of TN & $13.4^{\mathrm{e}}$ & $15.6^{\mathrm{d}}$ & $17.1^{\mathrm{c}}$ & $18.7^{\mathrm{b}}$ & $20.8^{\mathrm{a}}$ & 0.70 & $<0.001$ & $<0.001$ & 0.995 \\
\hline
\end{tabular}

Table 1. Chemical compositions of alfalfa, red clover, and their mixtures before ensiling 
proportions were detected among 5 treatments before ensiling. Wilted pure alfalfa contained 55.6 and $123 \%$ more FAA-N and $\mathrm{NH}_{3}-\mathrm{N}$ proportions than pure red clover, respectively.

\section{Fermentation Parameters of Silage}

During the ensiling of legumes, all treatments had a rapid decrease in $\mathrm{pH}$ during the first $3 \mathrm{~d}$ and the trend continued until the end of ensiling. Lactic acid concentration increased rapidly during the first $3 \mathrm{~d}$ and kept increasing slowly until d 30 (Figure 1a, 1b). After $30 \mathrm{~d}$ of ensiling, with increasing proportion of red clover, silage $\mathrm{pH}$ decreased linearly (Table 2), with R100 having the lowest $\mathrm{pH}$ and R50 having lower $\mathrm{pH}$ than R0 and R70. After $30 \mathrm{~d}$ of ensiling, lactic acid concentration linearly increased with increasing proportion of red clover, with the highest concentration observed in R100 silage, intermediate concentrations in R50 and R70, and lowest in R0 and R30. Acetic acid concentration rose during the first $15 \mathrm{~d}$ and decreased slightly from d 15 to 30 (Figure 1c) and did not differ across treatments after $30 \mathrm{~d}$ of ensiling. Concentrations of propionic and butyric acid were stable $(<0.06$ and $<0.19 \%$ DM, respectively) during ensiling and were not affected by treatments after ensiling for $30 \mathrm{~d}$. Lactic to acetic acid ratio increased as the proportion of red clover increased linearly on d 30 .

\section{Nitrogen Distribution of Silage}

Total NPN, peptide-N, FAA-N, and $\mathrm{NH}_{3}-\mathrm{N}$ proportions of TN were affected by ensiling day, mixing ratio, and their interaction during the ensiling process (Figure 2). Proportion of NPN increased during the whole ensiling and most rapidly during the first $3 \mathrm{~d}$ in all treatments with the fastest increase observed in R0 silage (Figure 2a). The NPN proportion in R0 silage was consistently the highest among all treatments and decreased with increasing mixing ratio of red clover. Similarly, at the end of ensiling on d 30, NPN proportion was highest in R0 silage and linearly decreased with increasing ratio of red clover (Table 2). Proportion of NPN in R50 was numerically closer to that of R100 than $\mathrm{R} 0$ on d 30 (7.1 vs. $5.6 \%$ TN). Peptide-N proportion increased during the first $7 \mathrm{~d}$, and declined for all treatments except R100, which remained stable after d 7. At the end of ensiling on d 30, peptide-N proportion was decreased in R50, R70, and R100 silage relative to R0. Proportion of FAA-N increased during the first $3 \mathrm{~d}$ for all treatments except R0, R30, and R50, thereafter declined from $\mathrm{d} 3$ to 7 and increased until the end of ensiling regardless of treatments. Across all ensiling times, FAA-N decreased with increasing red clover proportion; R0 had a higher FAA-N proportion than R50, R70, and R100. However, after $30 \mathrm{~d}$ of ensiling, only the proportion of FAA-N in R100 silage was lower than R0 (Table 2). Proportion of $\mathrm{NH}_{3}-\mathrm{N}$ continually increased throughout the ensiling for all treatments with R0 constantly having the greatest $\mathrm{NH}_{3}-\mathrm{N}$ proportion and R100 the lowest proportion. On d $30, \mathrm{NH}_{3}-\mathrm{N}$ proportion was
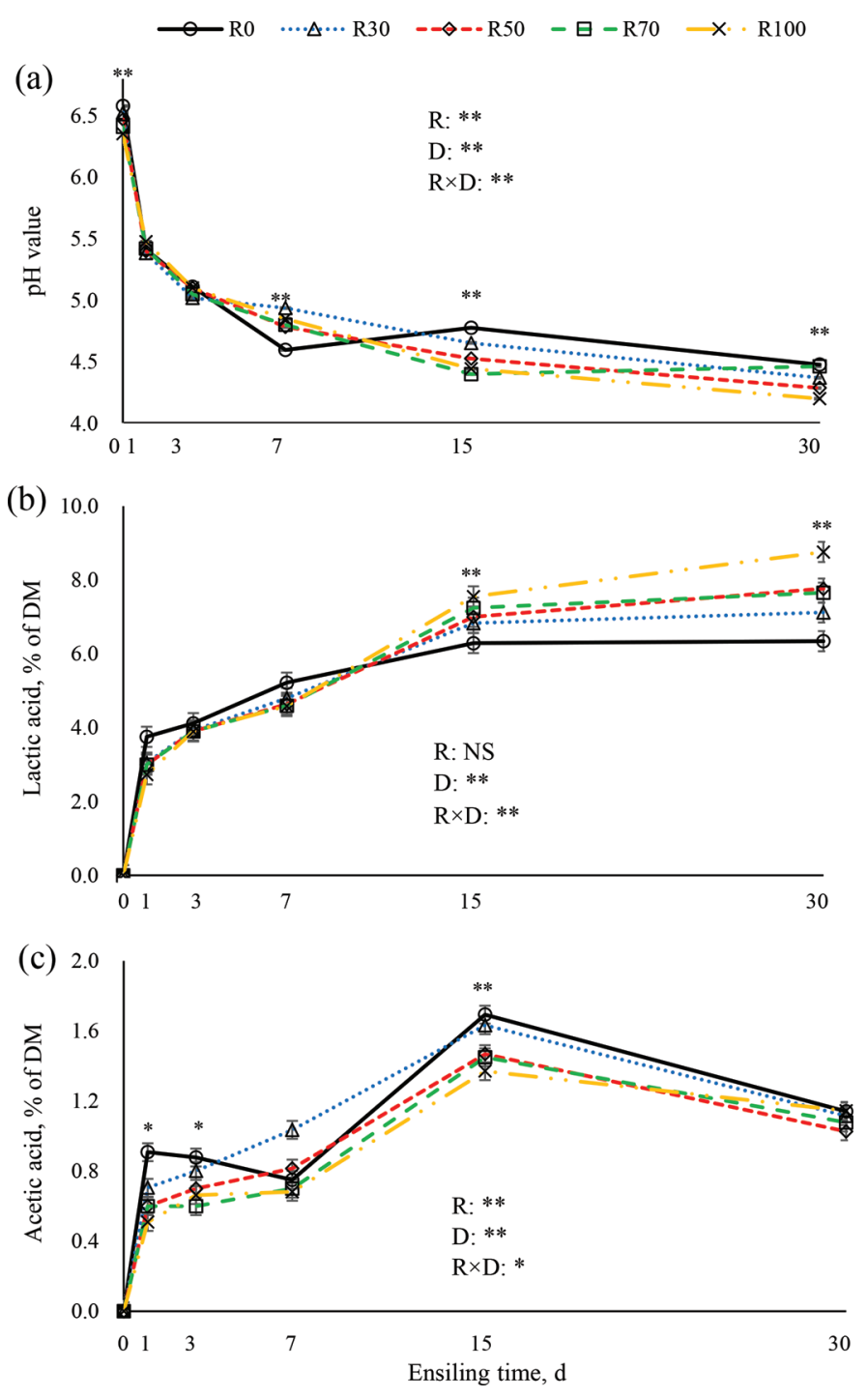

Figure 1. Effects of alfalfa to red clover ratio on dynamics of (a) $\mathrm{pH}$, (b) lactic acid, and (c) acetic acid concentration of silage. R0, R30, R50, R70, and R100 represent mixing ratio of red clover to alfalfa at 0:100, 30:70, 50:50, 70:30, and 100:0, respectively (fresh-weight basis). $\mathrm{R}=$ effects of mixing ratio; $\mathrm{D}=$ effects of ensiling day; $\mathrm{R} \times \mathrm{D}=$ effects of interaction between mixing ratio and ensiling day. Error bars represent SEM. Asterisks $\left({ }^{*} P \leq 0.05 ;{ }^{*} P \leq 0.01\right)$ indicate that concentrations were different at the specified opening day. NS, $P>0.05$. Color version available online. 
Table 2. Effects of alfalfa to red clover ratio on fermentation parameters, $\mathrm{N}$ distribution, and protein fractions of silage on d 30

\begin{tabular}{|c|c|c|c|c|c|c|c|c|c|}
\hline Item & \multicolumn{5}{|c|}{ Treatment $^{1}$} & SEM & \multicolumn{3}{|c|}{$P$-value ${ }^{2}$} \\
\hline \multicolumn{10}{|l|}{ Fermentation parameter } \\
\hline Lactic acid, \% of DM & $6.34^{\mathrm{c}}$ & $7.12^{\mathrm{bc}}$ & $7.77^{\mathrm{b}}$ & $7.66^{\mathrm{b}}$ & $8.76^{\mathrm{a}}$ & 0.28 & 0.002 & $<0.001$ & 0.996 \\
\hline Acetic acid, $\%$ of DM & 1.14 & 1.11 & 1.03 & 1.08 & 1.14 & 0.07 & 0.77 & 0.92 & 0.29 \\
\hline Lactic acid/acetic acid & 5.61 & 6.58 & 7.68 & 7.11 & 7.66 & 0.59 & 0.14 & 0.03 & 0.31 \\
\hline \multicolumn{10}{|l|}{ Nitrogen distribution $^{3}$} \\
\hline $\mathrm{TN}, \%$ of $\mathrm{DM}$ & $2.94^{\mathrm{a}}$ & $2.79^{\mathrm{ab}}$ & $2.83^{\mathrm{ab}}$ & $2.74^{\mathrm{bc}}$ & $2.61^{\mathrm{c}}$ & 0.05 & 0.006 & $<0.001$ & 0.73 \\
\hline NPN, $\%$ of TN & $48.1^{\mathrm{a}}$ & $44.1^{\mathrm{b}}$ & $41.0^{\mathrm{bc}}$ & $38.4^{\text {cd }}$ & $35.4^{\mathrm{d}}$ & 1.19 & $<0.001$ & $<0.001$ & 0.57 \\
\hline Peptide-N, $\%$ of TN & $26.1^{\mathrm{a}}$ & $22.8^{\mathrm{ab}}$ & $21.0^{\mathrm{bc}}$ & $17.0^{\mathrm{c}}$ & $20.5^{\mathrm{bc}}$ & 1.18 & 0.004 & 0.001 & 0.02 \\
\hline FAA-N, $\%$ of TN & $14.7^{\mathrm{a}}$ & $15.2^{\mathrm{a}}$ & $14.6^{\mathrm{a}}$ & $14.4^{\mathrm{a}}$ & $10.5^{\mathrm{b}}$ & 0.58 & 0.001 & $<0.001$ & 0.002 \\
\hline $\mathrm{NH}_{3}-\mathrm{N}, \%$ of $\mathrm{TN}$ & $7.32^{\mathrm{a}}$ & $6.06^{\mathrm{b}}$ & $5.40^{\mathrm{b}}$ & $7.04^{\mathrm{a}}$ & $4.40^{\mathrm{c}}$ & 0.26 & $<0.001$ & $<0.001$ & 0.38 \\
\hline \multicolumn{10}{|l|}{ Protein fraction ${ }^{4}$} \\
\hline
\end{tabular}

\footnotetext{
${ }^{\mathrm{a}-\mathrm{d}}$ Mean values in the same row with different superscripts differed $(P<0.05)$.

${ }^{1}$ Alfalfa and red clover was mixed on a fresh weight basis at a ratio of 100:0 (R0), 70:30 (R30), 50:50 (R50), 30:70 (R70), and 0:100 (R100). The ratio of alfalfa and red clover in R0, R30, R50, R70, and R100 on a DM basis was 100:0, 77:23, 58:42, 38:62, and 0:100, respectively.

${ }^{2} \mathrm{~T}=$ treatment effects; $\mathrm{L}=$ linear effects; $\mathrm{Q}=$ quadratic effects.

${ }^{3} \mathrm{TN}=$ total $\mathrm{N} ; \mathrm{FAA}-\mathrm{N}=$ free amino acid $\mathrm{N}$.

${ }^{4} \mathrm{PA}_{2}(\%$ of $\mathrm{TN})=$ buffer soluble $\mathrm{N}(\%$ of $\mathrm{TN})-\mathrm{NH}_{3}-\mathrm{N}(\%$ of $\mathrm{TN})$, soluble protein; $\mathrm{PB}_{1}(\%$ of $\mathrm{TN})=100-\mathrm{NH}_{3}-\mathrm{N}(\%$ of $\mathrm{TN})-\mathrm{PA}_{2}(\%$ of $\mathrm{TN})$ $-\mathrm{PB}_{2}(\%$ of TN $)-\mathrm{PC}\left(\%\right.$ of TN), insoluble true protein; $\mathrm{PB}_{2}(\%$ of TN) = NDIN (\% of TN) - ADIN (\% of TN), fiber-bound protein; PC (\% of $\mathrm{TN})=\mathrm{ADIN}(\%$ of $\mathrm{TN})$, indigestible protein.
}

highest in the R0 and R70, intermediate in R30 and R50 silage, and lowest in R100 (Table 2). Proportion of $\mathrm{NH}_{3}-\mathrm{N}$ in R50 was significantly closer to R100 than R0 on d 30. Overall, after $30 \mathrm{~d}$ of ensiling, linear decreases in TN content and proportions of NPN, peptide-N, FAA-N, and $\mathrm{NH}_{3}-\mathrm{N}$ were observed with increasing proportion of red clover. Also, quadratic decreases with increasing proportion of red clover were observed on peptide-N and FAA-N proportions on d 30 .

\section{Protein Fractions (CNCPS) of Silage}

The dynamics of protein fractions defined by the CNCPS during the ensiling are shown in Figure 3. Proportion of $\mathrm{PA}_{1}$, same as $\mathrm{NH}_{3}-\mathrm{N}$, continually increased throughout the ensiling (Figure 2d). After $30 \mathrm{~d}$ of ensiling, increasing proportion of red clover reduced $\mathrm{PA}_{1}$ linearly. Fraction $\mathrm{PA}_{2}$ (soluble protein defined by the CNCPS) proportion decreased in the first $\mathrm{d}$ and from d 15 to 30. Proportion of $\mathrm{PA}_{2}$ in R0 was significantly higher than R70 and R100 on d 30. After a drastic decline during the first day, $\mathrm{PB}_{1}$ (insoluble true protein defined by the CNCPS) proportions continued a slightly decreasing trend until d 30 and were at similar levels for all treatments on $\mathrm{d} 30$. Proportion of $\mathrm{PB}_{2}$ (fiber-bound protein defined by the CNCPS) decreased during the first $3 \mathrm{~d}$ and kept relatively stable until $\mathrm{d} 30$. Although treatments did not differ in the $\mathrm{PB}_{2}$ fraction at $\mathrm{d} 30, \mathrm{~PB}_{2}$ increased linearly with proportion of red clover. Proportion of PC (indigestible protein defined by the CNCPS) continued at a relatively stable level after a slight increase during the first day. At the end of fermentation, PC proportion was linearly increased with increasing proportion of red clover.

\section{Protease Activities of Silage}

All 3 plant proteases measured had decreased activity during ensiling (Figure 4). Carboxypeptidase activity decreased drastically during the first $7 \mathrm{~d}$ and continued at a low level $\left(6.06-16.7 \mu M \alpha-\mathrm{NH}_{2} \cdot \mathrm{g}^{-1} \cdot \mathrm{h}^{-1}\right.$ DM of forage) until the end of ensiling. On $\mathrm{d} 3$, the activity of carboxypeptidase in R0, R30, R50, R70, and R100 silage reduced 95.8, 79.9, 86.2, 47.7, and $38.9 \%$ of the original activity, respectively. During the ensiling, carboxypeptidase activity decreased with increasing proportion of red clover with the lowest activity observed in R100, intermediate activity in R70 and R50, and highest activity in R0 and R30. The activity of aminopeptidase decreased rapidly during the first $3 \mathrm{~d}$ and continued to decrease until d 15, then was stable (1.50-2.06 units. $\mathrm{h}^{-1} \cdot \mathrm{g}^{-1} \mathrm{DM}$ of forage) until d 
30. Regardless of ensiling time, the aminopeptidase activity was lower in R50, R70, and R100 silage than R0, whereas no difference was observed among mixing ratios of R30, R50, R70, and R100 (Figure 4b). Acid proteinase activity decreased during the first $15 \mathrm{~d}$ and continued to be stable thereafter. As red clover proportion increased, the activity of acid proteinase decreased with lower activity observed in R50, R70, and R100 silage than R0 throughout the ensiling (Figure 4c).

\section{DISCUSSION}

After wilting, lower TN content, proportions of FAA$\mathrm{N}$ and $\mathrm{NH}_{3}-\mathrm{N}$ were detected in red clover than alfalfa. Consistent with Owens et al. (1999a,b), a higher degree of protein breakdown occurred in alfalfa forage than red clover during wilting. However, the proportions of NDIN and ADIN were not consistent with Purwin et al. (2014b), who reported alfalfa had higher proportions of NDIN and ADIN than red clover after wilting. One possible reason for this is that forage was chopped to a certain length before wilting in our study, during which
PPO was released from the cell, and reacted in generation of protein complexes (Macheix et al., 1991).

High moisture (above 75\%) of fresh alfalfa is usually thought as an adverse factor for ensiling because Clostridium is active in a moist environment, so alfalfa is commonly wilted before ensiling (Muck, 2010). It is difficult to get the same level of moisture content when ensiling alfalfa and red clover in experimental and farm scale. Thus, the DM contents in mixed legumes varied with proportion of red clover in this study. The results suggested that the DM content affected the level of efficiency of Lactobacillus plantarum inoculant during the ensiling (Muck, 1990). Similar to Marley et al. (2003), silage $\mathrm{pH}$ decreased with increasing proportion of red clover, which had lower DM content than alfalfa. Nevertheless, all treatments showed relatively good fermentation quality as the final $\mathrm{pH}$ was below 4.4 and the lactic acid concentration was greater than $6.34 \% \mathrm{DM}$ and the butyric acid concentration was below $0.19 \%$ DM. Fermentation quality might affect proteolysis of ensiled alfalfa as proteases are sensitive to $\mathrm{pH}$ and deamination might occur due to microbial activities (McKersie,
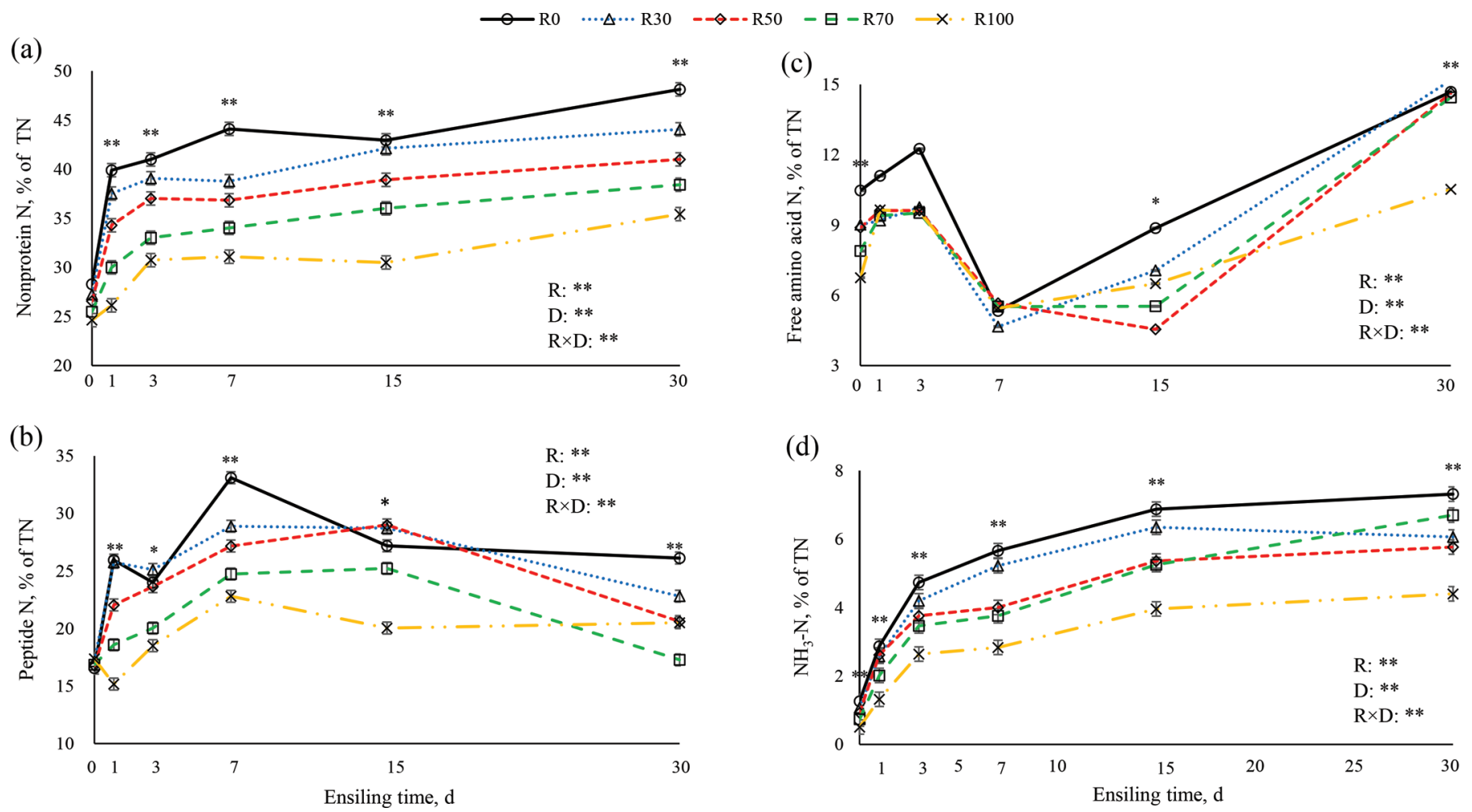

Figure 2. Effects of alfalfa to red clover ratio on dynamics of (a) NPN, (b) peptide $\mathrm{N}$, (c) free amino acid $\mathrm{N}_{\text {and }}$ (d) $\mathrm{NH}_{3}-\mathrm{N}$ proportion of silage. R0, R30, R50, R70, and R100 represent mixing ratio of red clover to alfalfa at 0:100, 30:70, 50:50, 70:30, and 100:0, respectively (freshweight basis). $\mathrm{R}=$ effects of mixing ratio; $\mathrm{D}=$ effects of ensiling day; $\mathrm{R} \times \mathrm{D}=$ effects of interaction between mixing ratio and ensiling day. Error bars represent SEM. Asterisks $\left(* P \leq 0.05 ;{ }^{* *} P \leq 0.01\right)$ indicate that concentrations were different at the specified opening day. TN $=$ total N. Color version available online. 
(a)

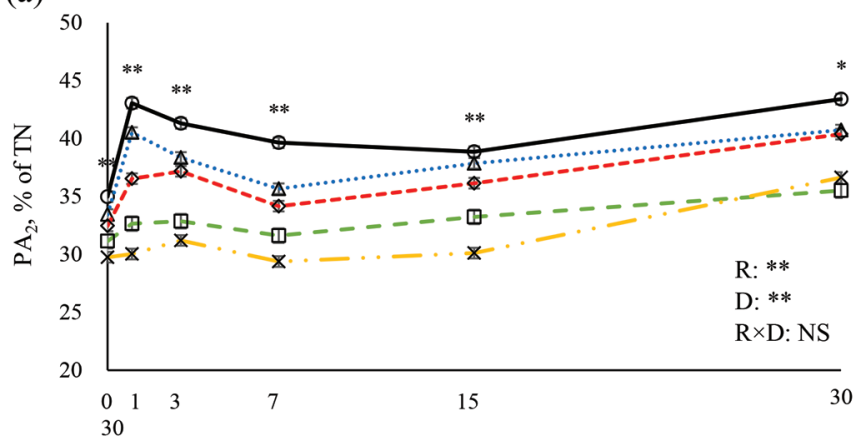

(b)

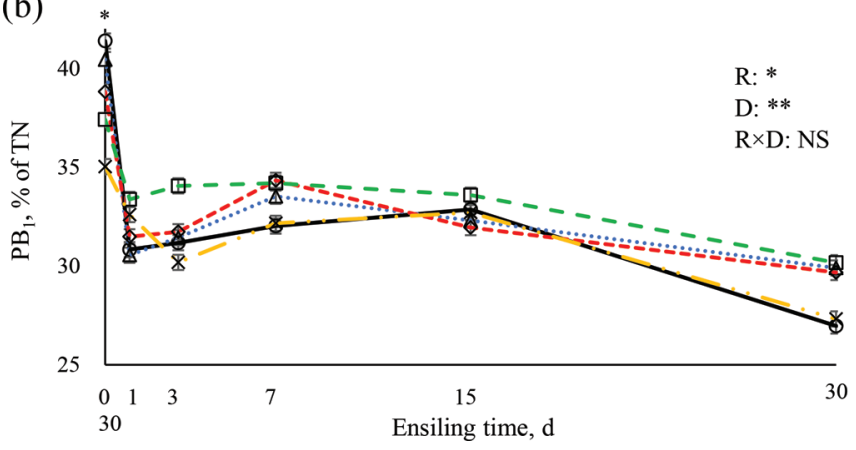

(c)

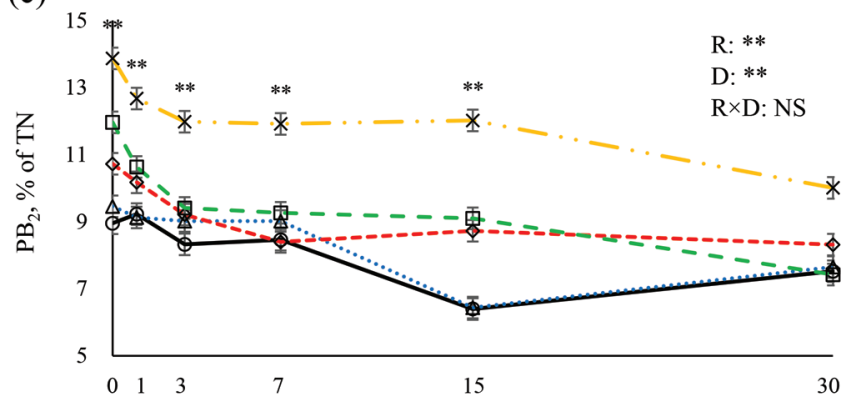

(d)

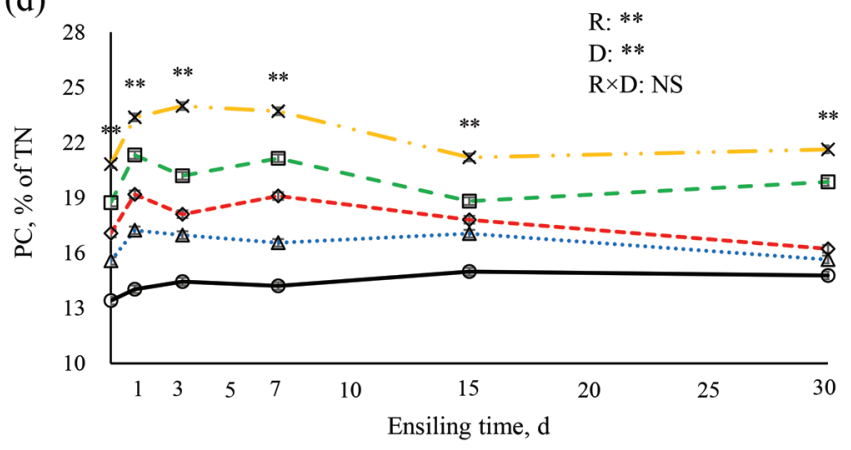

Figure 3. Effects of alfalfa to red clover ratio on dynamics of (a) $\mathrm{PA}_{2}$, (b) $\mathrm{PB}_{1}$, (c) $\mathrm{PB}_{2}$, and (d) $\mathrm{PC}$ proportion of silage. $\mathrm{PA}_{2}[\%$ of total $\mathrm{N}$ $(\mathrm{TN})]=$ buffer soluble $\mathrm{N}(\%$ of $\mathrm{TN})-\mathrm{NH}_{3}-\mathrm{N}(\%$ of TN$)$, soluble true protein; $\mathrm{PB}_{1}(\%$ of $\mathrm{TN})=100-\mathrm{NH}_{3}-\mathrm{N}(\%$ of $\mathrm{TN})-\mathrm{PA}_{2}(\%$ of $\mathrm{TN})-$ $\mathrm{PB}_{2}\left(\%\right.$ of TN) - PC (\% of TN), insoluble true protein; $\mathrm{PB}_{2}(\%$ of TN) = NDIN (\% of TN) - ADIN (\% of TN), fiber-bound protein; PC (\% of TN) = ADIN (\% of TN), indigestible protein. R0, R30, R50, R70, and R100 represent mixing ratio of red clover to alfalfa at 0:100, 30:70, 50:50, 70:30, and 100:0, respectively (fresh-weight basis). $\mathrm{R}=$ effects of mixing ratio; $\mathrm{D}=$ effects of ensiling day; $\mathrm{R} \times \mathrm{D}=$ effects of interaction between mixing ratio and ensiling day. Error bars represent SEM. Asterisks $\left({ }^{*} P \leq 0.05 ;{ }^{* *} P \leq 0.01\right)$ indicate that concentrations were different at the specified opening day. NS, $P>0.05$. Color version available online.

1985). In addition, the fermentation products (lactic and acetic acids) can suppress the microbial activities that are related to proteolysis (Muck, 2010). The final $\mathrm{pH}$, total and individual organic acid concentrations, and ratio of lactic and acetic acid on d 30 reflected that lactic acid bacteria dominated the microbial fermentation in all treatments.

Protein breakdown in ensiled forage proceeds through 2 major pathways. Whereas plant proteases dominate the process of true protein degradation (i.e., the first phase hydrolysis), microbial enzymes play a primary role in the conversion of FAA into $\mathrm{NH}_{3}$ (i.e., the second phase deamination, Ohshima and McDonald, 1978). In addition, microbial enzymes might also affect the protein hydrolysis during ensiling (Winters et al., 2000; Junges et al., 2017).

The dynamics of proportions of NPN, peptide-N, and $\mathrm{NH}_{3}-\mathrm{N}$ of alfalfa silage were consistent with Guo et al., (2007) and Yuan et al. (2017) except the decline in FAA-N proportion from d 3 to 7 , which might be due to the deamination, being more active than true protein hydrolysis. Red clover silage showed similar dynamic patterns of $\mathrm{N}$ distribution to alfalfa but no decline in peptide- $\mathrm{N}$ proportion was observed after the highest point. The linearly decreased proportions of NPN, peptide- $\mathrm{N}$, FAA-N, and $\mathrm{NH}_{3}-\mathrm{N}$ with increasing level of red clover indicated decreased proteolysis in the R30, R50, R70, and R100 treatments. The NPN proportion in R50 treatment was closer to R100 than R0 on d 30 numerically, which indicated that a beneficial effect from red clover component existed during the ensiling. Compared with alfalfa, red clover showed weaker proteolysis as expected (Purwin et al., 2014a). Although the reported literature has not focused on the dynamics of proteolysis in ensiled red clover, our study confirms that there were patterns of changes in the soluble $\mathrm{N}$ fractions with ensiling time similar to alfalfa even though concentrations may have been different across treatments.

As a direct indicator of hydrolysis (Licitra et al., 1996), NPN proportion was lower in red clover silage (R100) than alfalfa silage (R0) on d 30. The composition 


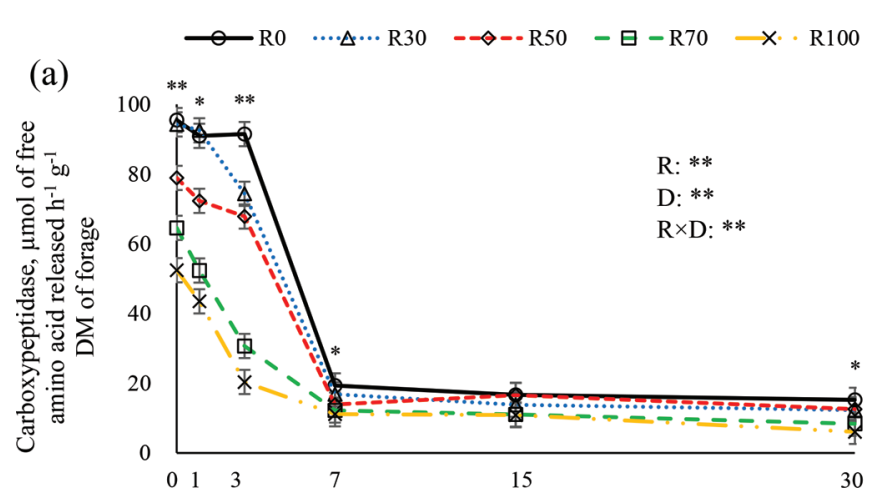

(b)
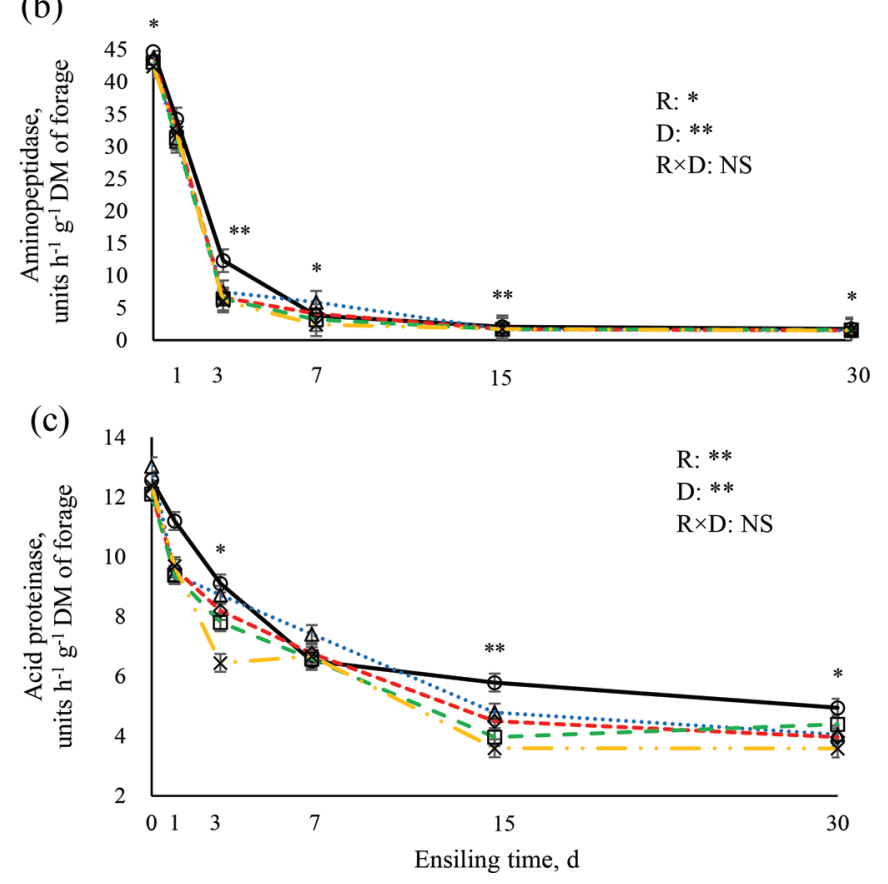

Figure 4. Effects of alfalfa to red clover ratio on dynamics of (a) carboxypeptidase, (b) aminopeptidase, and (c) acid proteinase activity of silage. R0, R30, R50, R70, and R100 represent mixing ratio of red clover to alfalfa at $0: 100,30: 70,50: 50,70: 30$, and 100:0, respectively (fresh-weight basis). $\mathrm{R}=$ effects of mixing ratio; $\mathrm{D}=$ effects of ensiling day; $\mathrm{R} \times \mathrm{D}=$ effects of interaction between mixing ratio and ensiling day. Error bars represent SEM. Asterisks $\left({ }^{*} P \leq 0.05\right.$; $\left.{ }^{* *} P \leq 0.01\right)$ indicate that concentrations were different at the specified opening day. NS, $P>0.05$. Color version available online.

of NPN is important as well (Fijałkowska et al., 2015a). Peptides are reported to be more efficiently used in the rumen compared with FAA (Johnson, 1976). Amino acid proportion with free forms can show differences in the hydrolytic properties of proteins (Fijalkowska et al., 2015a). However, changes in AA composition were not measured in the present study. Inconsistent with Fijałkowska et al. (2015b), peptide-N proportion of TN was lower in red clover silage than alfalfa (205 vs. $261 \mathrm{~g} / \mathrm{kg}$ of TN), but peptide-N proportion of NPN was higher ( 579 vs. $543 \mathrm{~g} / \mathrm{kg}$ of NPN). Moreover, a quadratic response of peptide- $\mathrm{N}$ proportion to increasing red clover proportion in the mixture (i.e., minimum value at R70) was found in this study. The lower FAA$\mathrm{N}$ proportion in R100 silages confirmed that the hydrolysis of true protein and peptide was weaker in red clover silage than alfalfa (Owens et al., 2002). Although FAA-N proportion decreased linearly and quadratically with increasing level of red clover, a lower FAA-N than R0 was only observed in R100 silage. This might be attributable to higher microbial protease activities in R0, R30, R50, and R70 silage than R100.

Ammonia content can be used to estimate the microbial activities in ensiled forage, because AA are broken down to $\mathrm{NH}_{3}$ by deamination, which is carried out by bacteria producing butyric, acetic, and lactic acid (Fijałkowska et al., 2015a). In addition, the low $\mathrm{NH}_{3}-\mathrm{N}$ concentration usually is accompanied by a low $\mathrm{pH}$ in ensiled alfalfa (Tian et al., 2017; Zhang et al., 2017). The dynamic pattern of $\mathrm{NH}_{3}-\mathrm{N}$ proportion in this study suggested the deamination was active throughout the ensiling and decreased with increasing red clover proportion in the mixture. It appears that for whatever reason there was more microbial proteolytic/deaminase activity as well as an increase in acid proteinase activity in R70 between d 15 and 30 (Figure 4c).

Peptide and FAA are hydrolysis products of true protein that can be consumed by microorganisms as substrates for deamination to produce $\mathrm{NH}_{3}$. Thus, they could reflect the relative activity between hydrolysis and deamination (Yuan et al., 2017). The quantitative change of peptide-N and FAA-N in this study indicated the protein hydrolysis was active during the first $3 \mathrm{~d}$ while deamination was active throughout the ensiling. And the peptide hydrolysis took place throughout the ensiling even from d 15 to 30 during when deamination was not as active as before. Because the protease activities were very low during that time, the production of FAA might be due to microbial activity (Winters et al., 2000).

The CNCPS was used to evaluate the protein quality and predict rates of protein digestibility in the rumen (Higgs et al., 2015). Results in this study were consistent with Nadeau et al. (2016) who reported NPN increased and indigestible true protein showed a slight rise after ensiling. The decreasing NPN proportion with increasing red clover proportion meant that efficient utilization of $\mathrm{N}$ by ruminant increased with increasing red clover proportion (Broderick, 1995). A negative correlation between in vitro ruminal degradability of insoluble $\mathrm{N}$ and urinary $\mathrm{N}$ excretion in sheep was reported by Nguyen et al. (2005). It can be estimated that $\mathrm{N}$ excretion decreases with increasing red clover 
proportion. Fraction $\mathrm{PB}_{1}$ is fermented in the rumen, and some escapes to the lower gut, whereas a high percentage of $\mathrm{PB}_{2}$ escapes degradation in the rumen (Sniffen et al., 1992). What can be predicted is that true protein escaped to lower gut increases as red clover proportion increases based on $\mathrm{PB}_{2}$ data. Fraction PC contains Maillard products, tannin-protein complexes, and protein associated with lignin that cannot be degraded by ruminal bacteria (Licitra et al., 1996). It is in agreement with Guo et al. (2008) that after ensiling, a higher PC proportion was observed than fresh legume, which might be caused by heat accumulation. Lower PC proportion in R30 and R50 silage than R100 on d 30 indicated a beneficial effect from alfalfa, resulting in higher protein digestibility than pure red clover silage (Broderick et al., 2001). Overall, data on all protein fractions suggested ensiling alfalfa with red clover would be effective to reduce $\mathrm{N}$ excretion and improve $\mathrm{N}$ utilization in the rumen (Broderick, 2018).

Primary plant enzymes in protein degradation of alfalfa are carboxypeptidase, aminopeptidase, and acid proteinase, which differ in optima such as $\mathrm{pH}$, temperature, and inhibitors (McKersie, 1981; McKersie and Buchanan-Smith, 1982). The optimal pH for carboxypeptidase and aminopeptidase activity in alfalfa are 5.4 and 6.5, respectively (McKersie, 1981). Acid proteinase activity is maximal at $\mathrm{pH} 5.5$ against azocasein in alfalfa (McKersie and Buchanan-Smith, 1982). In this study, aminopeptidase activity was the first of 3 proteases measured to decrease since the silage $\mathrm{pH}$ value was far below the optimum (Yuan et al., 2017). Carboxypeptidase and acid proteinase activities were active on $\mathrm{d} 1$ because the $\mathrm{pH}$ value (5.38 to 5.48) in ensiled legumes was close to the optimal $\mathrm{pH}$ of the 2 proteases (Guo et al., 2007). All 3 proteases showed a drastic decline in the initial stage of ensiling as expected (Russell et al., 1992). The dynamic patterns of proteases were similar in alfalfa and red clover, which were consistent with Jones et al. (1995a). The overall extent of proteolysis is dependent on silage $\mathrm{pH}$ because $\mathrm{pH}$ influences the activity and stability of proteases (Jones et al., 1995a). However, it cannot explain the difference in protease activities among 5 treatments in which no difference in $\mathrm{pH}$ was detected on $\mathrm{d} 1$ and 3 . The lower relative protease activity in the mixtures particularly on $\mathrm{d} 1$ and 3 possibly was due to the quinones by red clover PPO binding to the proteases (Lee et al., 2006; Sullivan and Hatfield, 2006). As expected, activities of 3 proteases decreased with increasing red clover proportion in the mixture. The activities of aminopeptidase and acid proteinase in $\mathrm{R} 50$ were closer to pure red clover silage than pure alfalfa, indicating the protease activities in alfalfa were inhibited by red clover.
In this study, red clover showed a weaker protein breakdown and lower protease activities during ensiling as expected (Nadeau et al., 2016). It suggests that alfalfa ensiled with red clover has the potential to inhibit proteolysis. When feeding to dairy cows, it is important to study the effects on intake and production, especially $\mathrm{N}$ efficiency and urinary $\mathrm{N}$ excretion. Thus, animal experiments on mixed silage are needed in the future.

\section{CONCLUSIONS}

The study showed that protein degradation and protease activities weakened as red clover proportion increased in the mixture without negative effects on fermentation quality in laboratory-scale silos. After ensiling, $\mathrm{pH}$ and the proportion of NPN, peptide-N, FAA$\mathrm{N}$ and $\mathrm{NH}_{3}-\mathrm{N}$ decreased, and lactic acid concentration increased linearly with increasing red clover proportion. Moreover, incorporation of red clover into alfalfa increased indigestible true protein. During ensiling, proteases including carboxypeptidase, aminopeptidase, and acid proteinase activities decreased as red clover proportion increased. The 50:50 ratio was the optimal mixing ratio of alfalfa with red clover, and showed good fermentation quality with lower $\mathrm{pH}$ and higher lactic acid concentration than pure alfalfa silage, weakened proteolysis with protease activities and $\mathrm{NH}_{3}-\mathrm{N}$ proportion closer to pure red clover silage than alfalfa, and also had more TN content than pure red clover silage. Research studies on $\mathrm{N}$ efficiency of alfalfa-red clover silage on dairy cows are needed in the future.

\section{ACKNOWLEDGMENTS}

The work was financially supported by China Forage and Grass Research System (CARS-34; Beijing), Agroscientific Research in the Public Interest (2014030482; Beijing, China), the Inner Mongolia Science and Technology Project (Ordos, China), the Special Fund for Agro-scientific Research in the Public Interest (201303061; Beijing, China), and the Chinese Universities Scientific Fund (2017QC027; Beijing).

\section{REFERENCES}

AOAC. 1990. Official Methods of Analysis. Assoc. Offic. Analyt. Chem., Arlington, VA.

Bittner, S. 2006. When quinones meet amino acids: Chemical, physical and biological consequences. Amino Acids 30:205-224. https://doi .org/10.1007/s00726-005-0298-2.

Broderick, G. A., R. P. Walgenbach, and S. Maignan. 2001. Production of lactating dairy cows fed alfalfa or red clover silage at equal dry matter or crude protein contents in the diet. J. Dairy Sci. 84:1728-1737. https://doi.org/10.3168/jds.S0022-0302(01)74608 -5 . 
Broderick, G. A. 1995. Performance of lactating dairy cows fed either alfalfa silage or alfalfa hay as the sole forage. J. Dairy Sci. 78:320329. https://doi.org/10.3168/jds.S0022-0302(95)76640-1.

Broderick, G. A. 2018. Utilization of protein in red clover and alfalfa silages by lactating dairy cows and growing lambs. J. Dairy Sci. 101:1190-1205. https://doi.org/10.3168/jds.2017-13690.

Broderick, G. A., and J. H. Kang. 1980. Automated simultaneous determination of ammonia and total amino acids in ruminal fluid and in vitro media. J. Dairy Sci. 63:64-75. https://doi.org/10 .3168/jds.S0022-0302(80)82888-8.

Cai, Y. 1999. Identification and characterization of enterococcus species isolated from forage crops and their influence on silage fermentation. J. Dairy Sci. 82:2466-2471. https://doi.org/10.3168/ jds.S0022-0302(99)75498-6.

Farmer, G. S., and G. H. Brusewitz. 1980. Use of home microwave oven for rapid determination of moisture in wet alfalfa. Trans. ASAE 23:170-172.

Feller, U. K., T.-S. S. Soong, and R. H. Hageman. 1977. Leaf proteolytic activities and senescence during grain development of fieldgrown corn (Zea mays L.). Plant Physiol. 59:290-294. https://doi .org/10.1104/pp.59.2.290.

Fijałkowska, M., B. Pysera, K. Lipiński, and D. Strusińska. 2015a. Changes of nitrogen compounds during ensiling of high protein herbages-A review. Ann. Anim. Sci. 15:289-305. https://doi.org/ 10.1515/aoas-2015-0008.

Fijałkowska, M., J. Wierzbowska, S. Sienkiewicz, B. Pysera, K. Lipiński, M. Stasiewicz, Z. Antoszkiewicz, and M. Fijałkowska. 2015b. The effect of ensiling in round bales on the content of nitrogen fractions in lucerne and red clover protein. J. Elem. 20:285291. https://doi.org/10.5601/jelem.2014.19.4.643.

Getachew, G., A. M. Dandekar, W. Pittroff, E. J. DePeters, D. H. Putnam, S. Goyal, L. Teuber, and S. Uratsu. 2009. Impacts of polyphenol oxidase enzyme expression in transgenic alfalfa on in vitro gas production and ruminal degradation of protein, and nitrogen release during ensiling. Anim. Feed Sci. Technol. 151:44-54. https://doi.org/10.1016/j.anifeedsci.2008.11.008.

Guo, X., H. Zhou, Z. Yu, and Y. Zhang. 2007. Changes in the distribution of nitrogen and plant enzymatic activity during ensilage of lucerne treated with different additives. Grass Forage Sci. 62:35-43. https://doi.org/10.1111/j.1365-2494.2007.00559.x.

Guo, X. S., W. R. Ding, J. G. Han, and H. Zhou. 2008. Characterization of protein fractions and amino acids in ensiled alfalfa treated with different chemical additives. Anim. Feed Sci. Technol. 142:89 98. https://doi.org/10.1016/j.anifeedsci.2007.07.005.

Higgs, R. J., L. E. Chase, D. A. Ross, and M. E. Van Amburgh. 2015. Updating the Cornell Net Carbohydrate and Protein System feed library and analyzing model sensitivity to feed inputs. J. Dairy Sci. 98:6340-6360. https://doi.org/10.3168/jds.2015-9379.

Johnson, R. R. 1976. Influence of carbohydrate solubility on non-protein nitrogen utilization in the ruminant. J. Anim. Sci. 43:184-191.

Jones, B. A., R. D. Hatfield, and R. E. Muck. 1995a. Characterization of proteolysis in alfalfa and red clover. Crop Sci. 35:537-541.

Jones, B. A., R. E. Muck, and R. D. Hatfleld. 1995b. Red clover extracts inhibit legume proteolysis. J. Sci. Food Agric. 67:329-333. https://doi.org/10.1002/jsfa.2740670309.

Junges, D., G. Morais, M. H. F. Spoto, P. S. Santos, A. T. Adesogan, L. G. Nussio, and J. L. P. Daniel. 2017. Short communication: Influence of various proteolytic sources during fermentation of reconstituted corn grain silages. J. Dairy Sci. 100:9048-9051. https:/ /doi.org/10.3168/jds.2017-12943.

Lee, M. R., J. de J. O. Colmenero, A. L. Winters, N. D. Scollan, and F. R. Minchin. 2006. Polyphenol oxidase activity in grass and its effect on plant-mediated lipolysis and proteolysis of Dactylis glomerata (cocksfoot) in a simulated rumen environment. J. Sci. Food Agric. 86:1503-1511. https://doi.org/10.1002/jsfa.2533.

Licitra, G., T. M. Hernandez, and P. J. Van Soest. 1996. Standardization of procedures for nitrogen fractionation of ruminant feeds. Anim. Feed Sci. Technol. 57:347-358. https://doi.org/10.1016/ 0377-8401(95)00837-3.

Macheix, J. J., J. C. Sapis, and A. Fleuriet. 1991. Phenolic compounds and polyphenoloxidase in relation to browning in grapes and wines. Crit. Rev. Food Sci. Nutr. 30:441-486. https://doi.org/10 $.1080 / 10408399109527552$

Marley, C. L., R. Fychan, M. D. Fraser, A. Winters, and R. Jones. 2003. Effect of sowing ratio and stage of maturity at harvest on yield, persistency and chemical composition of fresh and ensiled red clover/lucerne bi-crops. Grass Forage Sci. 58:397-406. https:/ /doi.org/10.1111/j.1365-2494.2003.00392.x.

Mayer, A. M. 1986. Polyphenol oxidases in plants-Recent progress. Phytochemistry 26:11-20.

McDonald, P., A. R. Henderson, and S. J. E. Heron. 1991. The Biochemistry of Silage. 2nd ed. Chalcombe Publications, Marlow, UK.

McKersie, B. D. 1981. Proteinases and peptidase of alfalfa herbage. Can. J. Plant Sci. 61:53-59.

McKersie, B. D. 1985. Effect of $\mathrm{pH}$ on proteolysis in ensiled legume forage. Agron. J. 77:81-86.

McKersie, B. D., and J. Buchanan-Smith. 1982. Change in the levels of proteolytic enzymes in ensiled alfalfa forage. Can. J. Plant Sci. 62:111-116.

Muck, R. E. 1987. Dry matter level effects on alfalfa silage quality I. nitrogen transformations. Trans. ASAE 30:7-14.

Muck, R. E. 1990. Dry matter level effects on alfalfa silage quality II. fermentation products and starch hydrolysis. Trans. ASAE 33:373-381.

Muck, R. E. 2010. Silage microbiology and its control through additives. Rev. Bras. Zootec. 39:183-191. https://doi.org/10.1590/ S1516-35982010001300021.

Nadeau, E., O. Hallin, W. Richardt, and J. Jansson. 2016. Protein quality of lucerne - A comparison to red clover and effects of wilting and ensiling. Pages 372-375 in The Multiple Roles of Grassland in the European Bioeconomy. Proceedings of the 26th General Meeting of the European Grassland Federation, Trondheim, Norway.

Nguyen, H. V., M. Kawai, J. Takahashi, and S. Matsuoka. 2005. Change in nitrogen fractions and ruminal nitrogen degradability of orchardgrass ensiled at various moisture contents and the subsequent effects on nitrogen utilization by sheep. Asian-australas. J. Anim. Sci. 18:1267-1272.

Ohshima, M., and P. McDonald. 1978. A review of the changes in nitrogenous compounds of herbage during ensilage. J. Sci. Food Agric. 29:497-505.

Owens, V. N., K. A. Albrecht, and R. E. Muck. 1999a. Protein degradation and ensiling characteristics of red clover and alfalfa wilted under varying levels of shade. Can. J. Plant Sci. 79:209-222. https: //doi.org/10.4141/P98-034.

Owens, V. N., K. A. Albrecht, and R. E. Muck. 2002. Protein degradation and fermentation characteristics of unwilted red clover and alfalfa silage harvested at various times during the day. Grass Forage Sci. 57:329-341. https://doi.org/10.1046/j.1365-2494.2002 .00333.x.

Owens, V. N., K. A. Albrecht, R. E. Muck, and S. H. Duke. 1999b. Protein degradation and fermentation characteristics of red clover and alfalfa silage. Crop Sci. 39:1873-1880.

Papadopoulos, Y. A., and B. D. Mckersie. 1983. A comparison of protein degradation during wilting and ensiling of six forage species. Can. J. Plant Sci. 63:903-912.

Peterson, L. W., and R. C. Huffaker. 1975. Loss of ribulose 1,5-bisphosphate carboxylase and increase in proteolytic activity during senescence of detached primary barley leaves. Plant Physiol. 55:1009-1015. https://doi.org/10.1104/pp.55.6.1009.

Purwin, C., M. Fijałkowska, B. Kowalik, Z. Nogalski, and B. Pysera. 2014a. The effect of bale density and addition of formic acid on the in situ dry matter and crude protein degradation of lucerne, red clover and red fescue silages. J. Anim. Feed Sci. 23:177-184. https: //doi.org/10.22358/jafs/65707/2014

Purwin, C., S. Sienkiewicz, B. Pysera, K. Lipiński, M. Fijałkowska, D. Piwczyński, and N. Puzio. 2014b. Nitrogen fractions and amino acid content in alfalfa and red clover immediately after cutting and after wilting in the field. J. Elem. 19:723-734. https://doi.org/10 $.5601 /$ jelem.2014.19.2.692

Russell, J. B., J. D. O'Connor, D. G. Fox, P. J. Van Soest, and C. J. Sniffen. 1992. A net carbohydrate and protein system for evaluat- 
ing cattle diets. 1. Ruminal fermentation. J. Anim. Sci. 70:35513561. https://doi.org/1992.70113562x.

Sniffen, C. J., J. O'Connor, P. Van Soest, D. Fox, and J. Russell. 1992. A net carbohydrate and protein system for evaluating cattle diets: II. Carbohydrate and protein availability. J. Anim. Sci. 70:3562-3577.

Sullivan, M. L., and R. D. Hatfield. 2006. Polyphenol oxidase and o-diphenols inhibit postharvest proteolysis in red clover and alfalfa. Crop Sci. 46:662-670. https://doi.org/10.2135/cropsci2005 .06-0132.

Sullivan, M. L., and W. E. Zeller. 2013. Efficacy of various naturally occurring caffeic acid derivatives in preventing post-harvest protein losses in forages. J. Sci. Food Agric. 93:219-226. https://doi .org/10.1002/jsfa.5781.

Tian, J., Z. Li, Z. Yu, Q. Zhang, and X. Li. 2017. Interactive effect of inoculant and dried jujube powder on the fermentation quality and nitrogen fraction of alfalfa silage. Anim. Sci. J. 88:633-642. https: //doi.org/10.1111/asj.12689.

Van Soest, P. J., J. B. Roberston, and B. A. Lewis. 1991. Methods for dietary fibre, neutral detergent fibre and non starch polysaccharides in relation to animal nutrition. J. Dairy Sci. 74:3583-3597.
Winters, A. L., J. E. Cockburn, M. S. Dhanoa, and R. J. Merry 2000. Effects of lactic acid bacteria in inoculants on changes in amino acid composition during ensilage of sterile and non-sterile ryegrass. J. Appl. Microbiol. 89:442-451. https://doi.org/10.1046/ j.1365-2672.2000.01133.x.

Xu, Q., Z. Yu, J. Han, C. Bai, Y. Xue, and G. Xun. 2007. Determining organic acid in alfalfa silage by HPLC. Grassl. Turf 2:63-67.

Yuan, X. J., A. Y. Wen, S. T. Desta, Z. H. Dong, and T. Shao. 2017. Effects of four short-chain fatty acids or salts on the dynamics of nitrogen transformations and intrinsic protease activity of alfalfa silage. J. Sci. Food Agric. 97:2759-2766. https://doi.org/10.1002/ jsfa.8103.

Zhang, Q.. Z. Yu, X. Wang, and R. Na. 2017. Effects of chlorpyrifos and chlorantraniliprole on fermentation quality of alfalfa (Medicago sativa L.) silage inoculated with or without Lactobacillus plantarum LP. Anim. Sci. J. 88:456-462. https://doi.org/10.1111/ asj.12637. 